\title{
Analysis of Education Financial Restructuring Strategies to Increase Human Resource Quality in Riau Province
}

\author{
$\mathrm{Kamsol}^{1}$, Maryunani $^{2}$, Susilo $^{2}$, Gozali $^{2}$ \\ ${ }^{1}$ Doctoral Program of Economics Science, Faculty of Economics and Business, University of Brawijaya \\ ${ }^{2}$ Faculty of of Economics and Business, University of Brawijaya, Indonesia
}

\begin{abstract}
The purpose of this study is to analyze the efficiency of secondary basic education financing in Riau province consisting of 12 districts/cities. Efficiency measurements by using analytical methods Data Envelopment Analysis (DEA).

In 2010, there were three districts/cities have reached the level of efficiency that is Indragiri Hulu, Meranti Island, and Rokan Hulu. In 2011, there was only one area that reaches the efficiency of education spending, that is Dumai. Subsequently, in 2012 Dumai and Meranti Islands achieve efficiency of education spending. Districts/cities that do not achieve the level of efficiency should make improvements. Potential improvement district/city of Riau Province in 2010 is on the input side, example the budget reductions. While on the output side, in the year 2010 does not need to be repaired. In contrast to the potential level of improvement in 2010, the overall improvement potential is not only done on the input side, but on the output side must also be repaired. That is, in 2011 the whole district/city must fix education spending, school capacity (the ratio of students to total number of schools), and the capacity of teachers to handle the students (the ratio of the number of students to the number of teachers). The overall potential improvement suggests the need for improvement through reduction $39,45 \%$ of education expenses, increase school capacity by 60,17\% and improve the capacity of teachers to handle the students was $0,37 \%$. That's all indicates that the need for revamping the persistence of wasteful spending that occurred in several districts/cities that do not achieve efficiency.

In 2012 the overall potential improvement that needs to be done in the form of improved inputs namely reduction education budget by 98,83 percent and the ratio of students per teacher was 1.17 percent. The need to reduce the education budget indicates that the use of the education budget in most district/cities in Riau province does not produce the maximum output. In other words, the output in 2012 should be generated through the budget in question. Thus, the use of the education budget in 2012 in most of the district/city is said to be inefficient. In addition, the existing budgets need capacity building of teachers in dealing with students.
\end{abstract}

Key Words: Education Financing and Quality of Human Resources

\section{Introduction}

Education in the perspective of economics is one part of the investment in human resources (HR). Investment in human resources is essential due to get a decent job with sufficient income then requires a person skills are good. In addition to the above factors, education is also an important element in reducing poverty, while the woman and save the children of various exploits (UNICEF Annual Report, 2010). The importance of education funding budgeted by the government has been carried out by Lindahl and Krueger (2001); Bose et al (2003), and Abijet (2010) has confirmed the influence of government funding to the education sector in particular economic development. Research related to the education budget allocation provided by the government was done by Mackenzie. Mackenzie (2011) explains that education spending in industrialized countries is 4,5 to $7 \%$ of GDP, in the other hand spending on education in developing countries is $2,5-7,5 \%$ of the GDP. This means that the average share of GDP that is used for greater education in industrialized countries compared to developing countries.

Gupta (2009) examined the issue of education spending is endogenous variables along with the literacy rate. The higher education spending more and more demand for services related to education so that education spending should be enlarged.There is a reciprocal relationship between literacy and education expenditure as a percentage of GNP. Other variables that affect the level of literacy is the GNP per capita and enrollment ratio. Sylwester (2012) explained that the state is paying more attention to education as a share of GDP have lower levels of inequality. This conclusion is an implication and the reason of the increase in human capital to spur economic growth.

Furthermore, Azariadis and Drazen (2009) find that the high quality of human resources (HR) is necessary but not sufficient to ensure the creation of high economic growth and sustainable. To be able to create externalities quality of human resources in the economy, education must reach the threshold (critical mass) is needed. In addition, the growth response to the quality of human resources often requires a fairly long time frame. 
Education can be seen as one of the investment (human investment), the process of knowledge and skills through education is not merely a form of consumption, but it is an investment. The same thought is also disclosed by Mark Blaug (2010:19) which states that: "A good case can be made for the view that educational expenditure does to a surprising degree partake of the nature of future investment in enhanced outputnow. To that extent, the consequences of education in the sense of skills embodied in people may be viewed as human capital which is not to say that people are being treated themselves capital. In other word, the maintenance and improvement of skills may be seen as an investment in human beings, but the resources devoted to maintaining and increasing the stock of human beings remain consumption by virtue of the abolition of slavery".

Therefore, education is an investment that is useful not only for the individual, but also an investment for society where the real education can provide a substantial contribution to a better life in the future. It can be concluded that the educational process is closely related to a concept called human capital. This is reinforced by the opinion of Jones (2011:4) which states that "The people have certain skills, habits, and knowledge which they sell to employers in the form of their salaried wage labor, and which can be expected to provide them a flow of income over their lifetimes. Furthermore, human capital can be analogized in some physical and capital respects because both are used together to produce a stream of income over some period of years".

In terms of economic theory of education, especially the human capital approach, the financing aspect is seen as part of the investment in education that determines the level of productivity of individuals and groups. This in turn affects the level of productivity of the acquisition stage (earning) a person or group that ultimately contribute to the quality of human resources and development. This thinking is conceptualized by Elchanan Cohn (2011)

\section{Research Methods}

This research was conducted in Riau province that consisting of 12 districts/ cities. The data used is panel data that is a combination of time series and cross section data. The panel data will provide more complete data information, more free and more efficient. Efficiency measurements beperformed using analytical methods Data Envelopment Analysis (DEA). Vow (2006) revealed that the DEA methodology is a non-parametric method that uses linear programming models to calculate the ratio of input and output for all units.

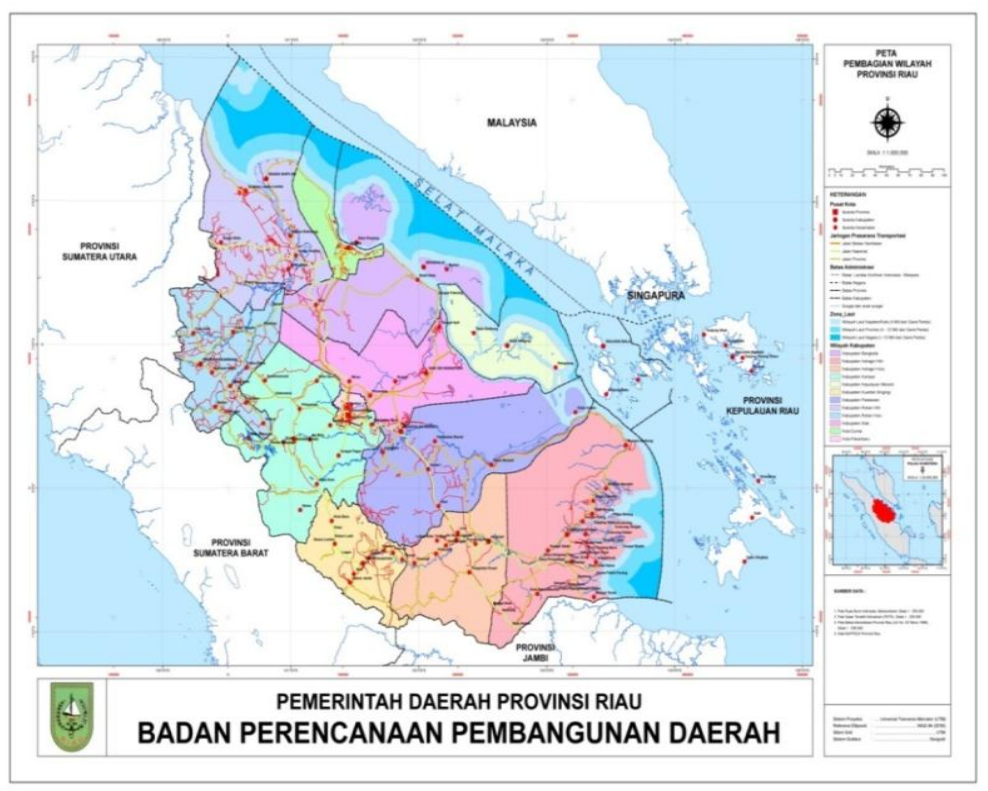

Figure 1. Research Location Map

Farrell (1957) divides the concept of efficiency into three categories, namely technical efficiency, allocation efficiency, and economical efficiency. Technical efficiency describes the ability of the unit to achieve maximum output level at a certain input level. Allocation efficiency demonstrates the ability of the unit to select the optimal combination of inputs at a certain level of price and technology. Furthermore, the two measurements can be combined to produce a broader measure that known as the "total economic efficiency" or the cost efficiency when the concern is not the cost of production.

This study used the technical efficiency type of measurement efficiency is the initial stage of the concept of efficiency that focuses on the ability of generating units using the input output compared to best practice or benchmarks. Vow (2006) explains that "technical efficiency is a combination of capacity and ability to produce 
economic units to a maximum output level of a number of inputs and technology ". Efficient condition will occur if the magnitude of a certain amount of government spending can produce optimum output.

The method uses DEA efficiency measurement basis is as follows :

efficiency $=\frac{\text { Output }}{\text { Input }}=\frac{\text { virtwaloutput }}{\text { virtualinput }}=\frac{\sum_{r=1}^{S} U_{r} X_{Y}}{\sum_{i=1}^{m} V_{i} X_{i}} \quad$ (Cooper et all, 2000:15)

or $\frac{u_{i} y_{i}+u_{2} y_{2}+\cdots+u_{g} y_{S}}{v_{1} x_{1}+v_{2} x_{2}+\cdots+v_{m} x_{m}}$

where :

$$
\begin{aligned}
& y_{r}=\text { amount of output } \mathrm{r} \\
& u_{r}=\text { weight of output } \mathrm{r} \\
& x_{i}=\text { amount of output } \mathrm{i} \\
& v_{i}=\text { weight of output } \mathrm{i}
\end{aligned}
$$

In DEA, the relative efficiency unit of economic activity (UKE) is defined as the ratio of divided weighted total output and total weighted input. DEA is used to determines the weights (weights) or scales for each output and input UKE. Each UKE in the sample should be able to use the same set of weights to evaluate the ratio (total weighted output / total weighted input) and the ratio should not be more than 1 (total weighted output / total weighted input $<1)$. The weights have no negative properties, and universal.The concept of DEA graphically is as follows:

output 2/Input

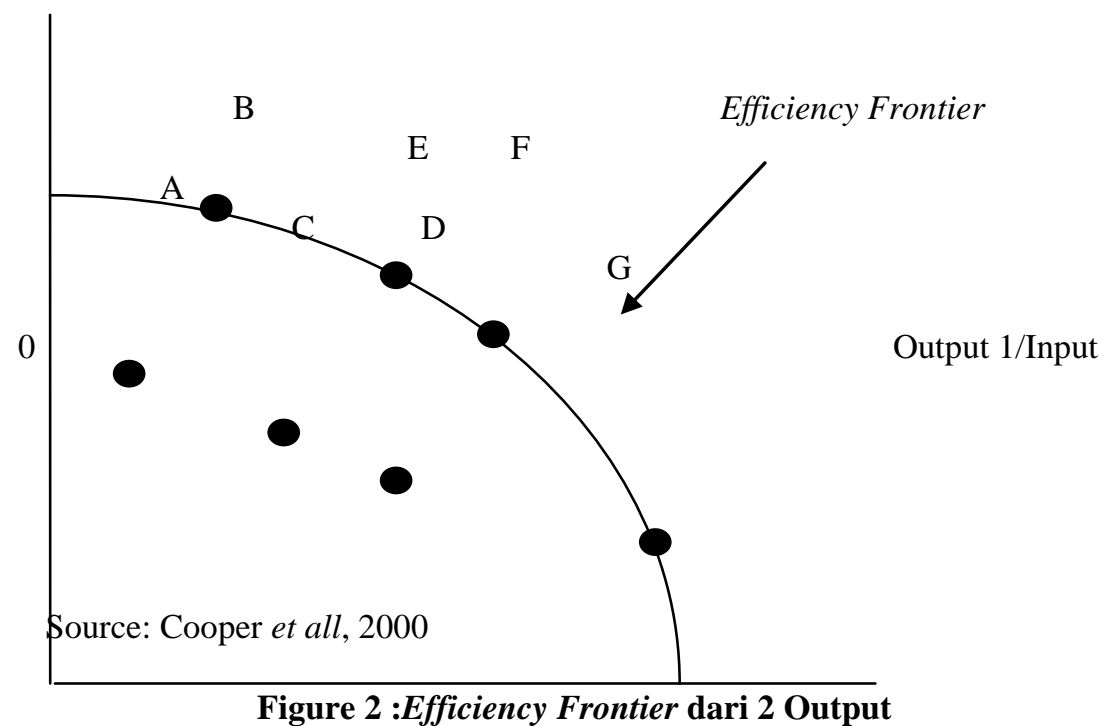

The curve above is the explanation for the efficiency calculation consisting of one input and two outputs. Efficiency frontier shows the points of efficient and inefficient. The points that exist along Efficiency is UKE efficient frontier, while existing outside line is not efficient. The level of efficiency can be evaluated using the boundary line. For example, point D is UKE inefficient, then the efficiency is assessed by:

$\frac{d(O, D)}{d(O, P)}$, where $d(O, D)$ is the distance from zero to $\mathrm{D}$ and and $\mathrm{d}(\mathrm{O}, \mathrm{P})$ range from zero to $\mathrm{P}$ which can be described as follows: 


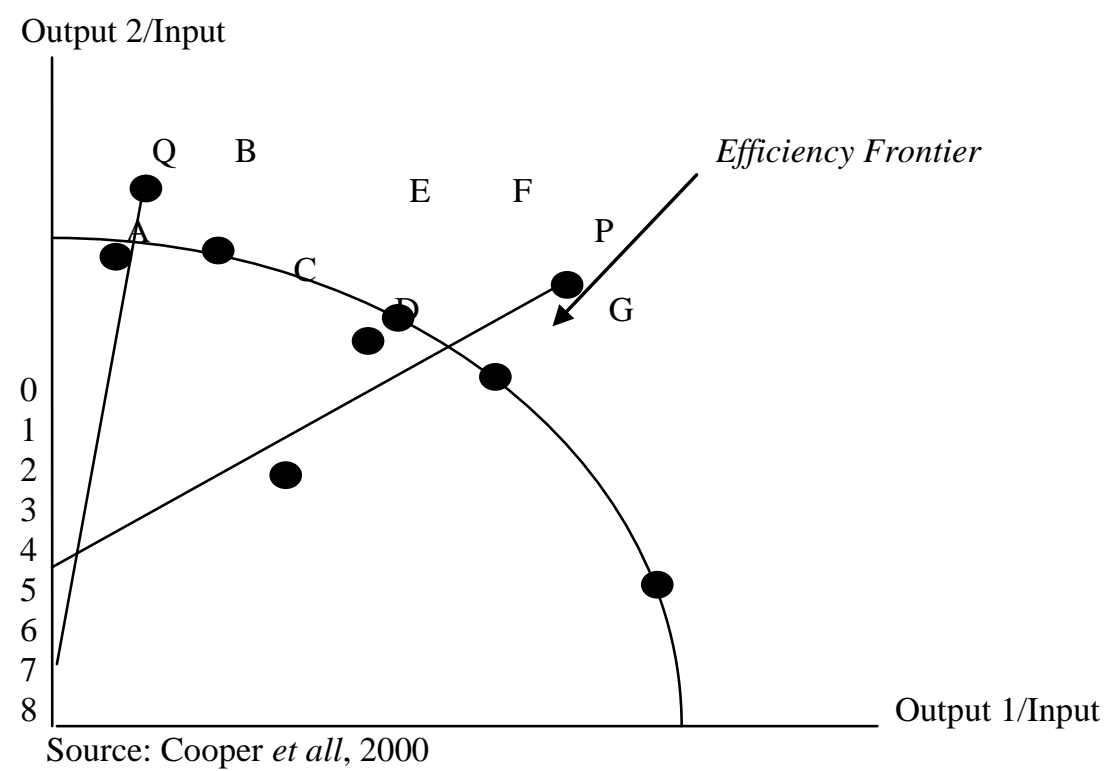

Figure 3.Improvement

The curves above show that improvements can be made by UKE D. D output can be improved by increasing both its output without changing the proportions until it reaches the point P. DEA models can also be formulated into fractional form by making the inputs and outputs of certain UKE as a decision variable. Each UKE uses a number of $\mathrm{m}$ inputs and number of s outputs (Prasetya, 2006). This method is also used to measure each of the UKE. Settlement based on fractional program constraints to determine the weights of the input weights (vi) $(\mathrm{i}=1, \ldots \mathrm{m})$ and output weights (ur) $(\mathrm{r}=1, \ldots . \mathrm{a})$ as variables (Cooper et all, 2000: 23)

(FPo) $\max \theta=\frac{u_{i} y_{10}+u_{2} y_{20}+\cdots+u_{g} y_{S 0}}{v_{i} x_{10}+v_{2} x_{20}+\cdots+v_{m} x_{m 0}}$

Subject to

$$
\frac{w_{1} y_{1 j}+\cdots+u_{g} y_{s j}}{v_{1} x_{1 j}+\cdots+v_{m}} \leq 1(j=1, \ldots, n)
$$

$v_{1}, v_{2}, \ldots, v_{m} \geq 0$

$v_{1}, v_{2}, \ldots, v_{s} \geq 0$

Completion by the constraints of fractional programs, limiting non negativity is mathematically not enough to produce a definitive value The above fractional program transformed into a linear program (LPo) that would solve the problem by the simplex method to obtain the optimal solution. Furthermore, each input and output variables can be directly incorporated into a linear program without having to have the same measurement unit (Nugroho, 1995 in Prasetya, 2006), so the shape of the transformation is as follows:

$$
\begin{aligned}
& \left(L P_{o}\right) \max \theta=u_{1} y_{10}+\cdots+u_{s} y_{s o} \\
& \text { Subject to } v_{1} x_{10}+\cdots+v_{m} x_{m o}=1 \\
& u_{1} y_{1 j}+\cdots+u_{s} y_{s j} \leq v_{1} x_{1 j}+\cdots+x_{m} x_{m j}(j=1, \ldots, n) \\
& v_{1}, v_{2}, \ldots, v_{m} \geq 0 \\
& u_{1}, u_{2}, \ldots, u_{s} \geq 0
\end{aligned}
$$

DEA has three advantages. First, efficiency DEA for each UKE, and relative to others UKEin the sample. The efficiency rate allows researchers to identify the UKE most need of attention and remedial action plan for the UKE is not or less efficient. Second, if UKE less efficient (efficiency $<100 \%$ ), DEA indicates that a number of UKE has perfect efficiency and a set of multiplier which can be used to improvement strategies. Such information helps the researcher to make UKE hypothesis using fewer inputs and produce outputs at least the same or more than the UKE is not efficient, so the hypothesis UKE will have perfect efficiency when using the weights of the input or output weights UKE inefficient. Third, DEA provides cross efficiency matrix. Crossefficiency UKE A to B is a ratio of weighted outputs divided by weighted inputs are calculated using the input and output levels UKE A and the input and output weights UKE B. Analysis of cross- efficiency can help a 
researcher to recognize UKE efficient but uses a combination of input and output combinations that produce very different from the other UKE.

\section{Efficiency of The Education Budget}

\section{Empirical Result}

The level of efficiency of each city district in 2010-2012 was not the same. In 2010, there were three districts/cities have reached the level of efficiency that is Indragiri Hulu, Meranti Islands Regency, and Rokan Hulu. Later, in 2011, there was only one area that achieve efficiency of education spending, which Dumai. Subsequently, in 2012 Dumai and Meranti Islands achieve efficiency of education spending again. The development of performance efficiency of the district/city in the province of Riau in detail is as follows.

Tabel 1. Performance of education efficiency of the district in the Riau province

\begin{tabular}{|c|c|c|c|c|}
\hline \multirow{2}{*}{ No } & & \multicolumn{3}{|l|}{2010} \\
\hline & Unit name & Score & Efficient & Condition \\
\hline \multirow{12}{*}{2010} & Bengkalis & $32.90 \%$ & & \\
\hline & Dumai & $33.10 \%$ & & \\
\hline & Indragiri Hilir & $11.10 \%$ & & \\
\hline & Indragiri Hulu & $100.00 \%$ & $\checkmark$ & \\
\hline & Kampar & $7.00 \%$ & & \\
\hline & Kepulauan Meranti & $100.00 \%$ & $\checkmark$ & \\
\hline & Kuantan Singingi & $11.60 \%$ & & \\
\hline & Pekanbaru & $6.60 \%$ & & \\
\hline & Pelalawan & $59.10 \%$ & & \\
\hline & Rokan Hilir & $16.80 \%$ & & \\
\hline & Rokan Hulu & $100.00 \%$ & $\checkmark$ & \\
\hline & Siak & $12.20 \%$ & & \\
\hline
\end{tabular}

\begin{tabular}{|l|l|l|l|l|}
\hline \multirow{5}{*}{} & Bengkalis & $33.60 \%$ & & \\
\hline & Dumai & $100.00 \%$ & $\checkmark$ & \\
\hline & Indragiri Hilir & $20.50 \%$ & & \\
\hline & Indragiri Hulu & $76.80 \%$ & & \\
\hline & Kampar & $74.60 \%$ & & \\
\hline & Kepulauan Meranti & $78.40 \%$ & & \\
\hline & Kuantan Singingi & $60.30 \%$ & & \\
\hline & Pekanbaru & $26.90 \%$ & & \\
\hline & Pelalawan & $93.70 \%$ & & \\
\hline & Rokan Hilir & $64.40 \%$ & & \\
\hline & Rokan Hulu & $79.70 \%$ & & \\
\hline & Siak & $30.70 \%$ & & \\
\hline
\end{tabular}




\begin{tabular}{|l|l|l|l|l|}
\hline \multirow{5}{*}{} & Bengkalis & $34.90 \%$ & & \\
\cline { 2 - 5 } & Dumai & $100.00 \%$ & $\checkmark$ & \\
\hline & Indragiri Hilir & $29.30 \%$ & & \\
\hline & Indragiri Hulu & $54.90 \%$ & & \\
\hline & Kampar & $18.80 \%$ & & \\
\hline & Kepulauan Meranti & $100.00 \%$ & $\checkmark$ & \\
\hline & Kuantan Singingi & $37.60 \%$ & & \\
\hline & Pekanbaru & $34.70 \%$ & & \\
\hline & Pelalawan & $50.90 \%$ & & \\
\hline & Rokan Hilir & $34.70 \%$ & & \\
\hline & Rokan Hulu & $44.20 \%$ & & \\
\hline & Siak & $41.30 \%$ & & \\
\hline
\end{tabular}

source: DEA processed, 2013

In 2010 needs to be improved inputs in the form of the education budget reduction. That's all indicates that the use of the education budget in most districts/cities in Riau province does not produce the maximum output. In other words, the output in 2010 should be generated through the budget in this period. The use of the education budget in 2010 in most of the district/city is said to be inefficient. In detail, the overall improvement of the district/city to achieve the level of efficiency is as follows.

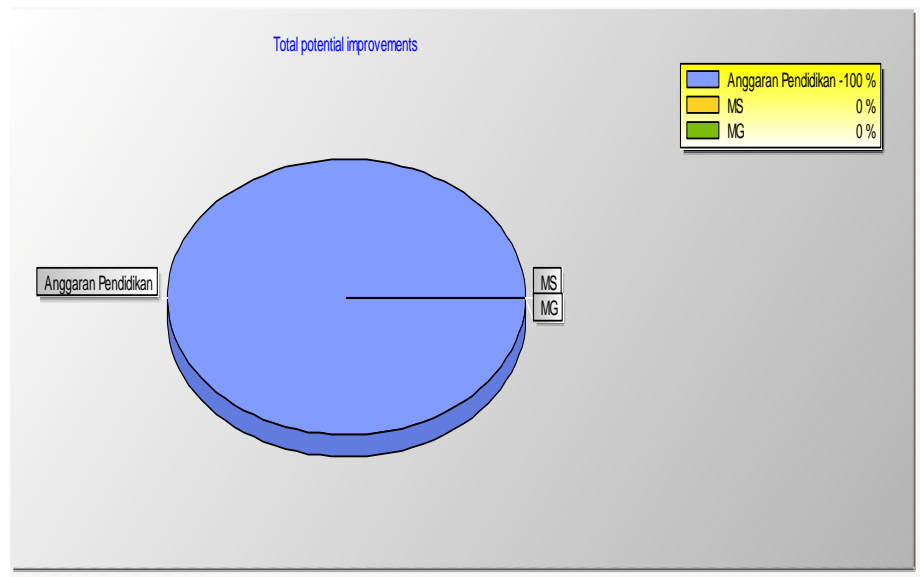

Source:DEA processed, 2013

Figure 4. Total Potential Overall Improvement Input/Output 2010

From the all district / city in the province of Riau, Meranti Island, Rokan Hulu and Indragiri Hulu were efficient in the area of education expenditures, the achievement rate of 100 percent efficiency. While the others districtsare not. This is due, with the existing budget, should have a greater absorption of the number of students by the number of schools available. It can be said also, that the number of schools that are yet to be fully utilized. In addition, the magnitude of the budget should be able to increase the number of students along with the availability of the number of teachers in each district/city that does not achieve efficiency. In other words, teachers in some of the region should be able to handle more students. The efficiency level of each county/city in Riau province are as follows. 


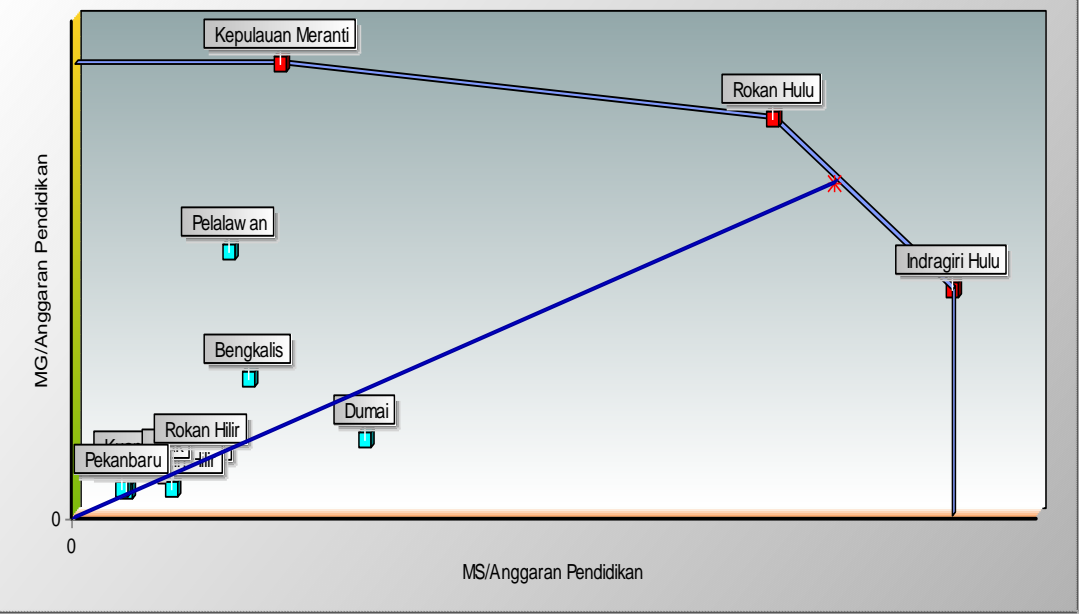

Source:DEA processed, 2013

Figure 5. Efficiency Probability Rate

Some cities that do not achieve the level of efficiency should make improvements. In the analysis of efficiency, the rate of improvement is often called the potential improvement that values varied between districts / cities. Potential improvement district / city of Riau Province in 2010 is on the input through side of the budget reductions. While on the output side, in the year 2010 does not need to be repaired.

Bengkalis need to reduce the education budget by 67,08 percent to reach a level of efficiency. Similarly, Dumai needs to reduce education spending by 66,91 percent to reach a level of efficiency. Then Indragiri Hilir, need to reduce the budget by 88,90 percent to have this level of efficiency. Furthermore, Kampar district also needs to cut education budget by 93,01 percent. The Kuantan Singingi inputs need improvement by reducing the budget by 88,35 percent. Still the same as some other areas, each Pekanbaru, Pelalawan, Rokan Hilir, and Siak must reduce education spending by 93,39 percent, 40,87 percent, 83,20 percent and 87,79 percent to reach level of efficiency.

In contrast to the overall potential level of improvement in 2010 is not only done on the input side, but on the output side must also be repaired. This means that in 2011 the whole district/city must fix education spending, school capacity (the ratio of students to total number of schools), and the capacity of teachers to handle the students (the ratio of the number of students to the number of teachers). Potential overall improvement suggests the need for improvement through reduction of 39,45 percent for education expenses, increase school capacity by 60,17 percent and increase the capacity of teachers to handle the students by 0,37 percent. The result indicates that the need for revamping the persistence of wasteful spending that occurred in several districts/cities that do not achieve efficiency.

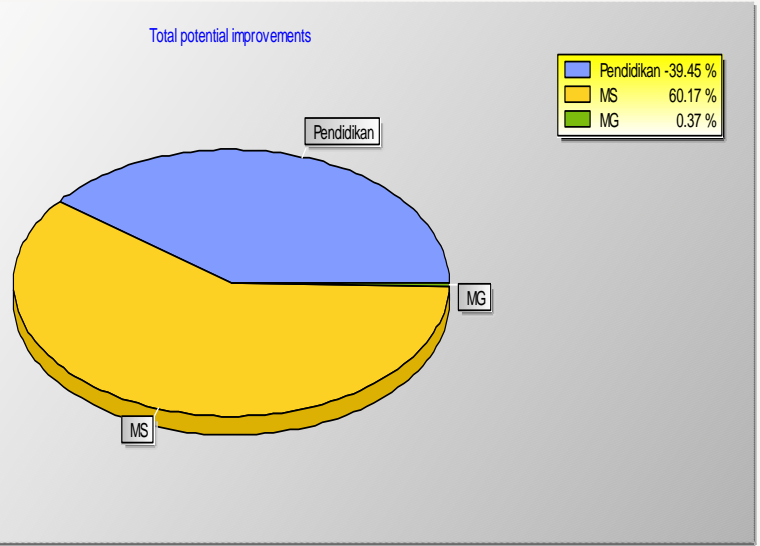

Source:DEA processed, 2013

Figure 6.Potential Overall Improvement Input/Output District The Province of Riau 2011 
In 2011, only Dumai who reached an efficiency in 100 percent. While other areas, need to make improvements both in terms of input and output to achieve the level of efficiency. Efficiency was achieved by Dumai, one of which is caused due to the minimal use of inputs, outputs greater performance compared with other districts. It can be said Dumai has efficiently in education spending. While the other districts/cities categorized inefficient, because the allocation of greater spending, but the resulting output is lower than the output produced by Dumai.

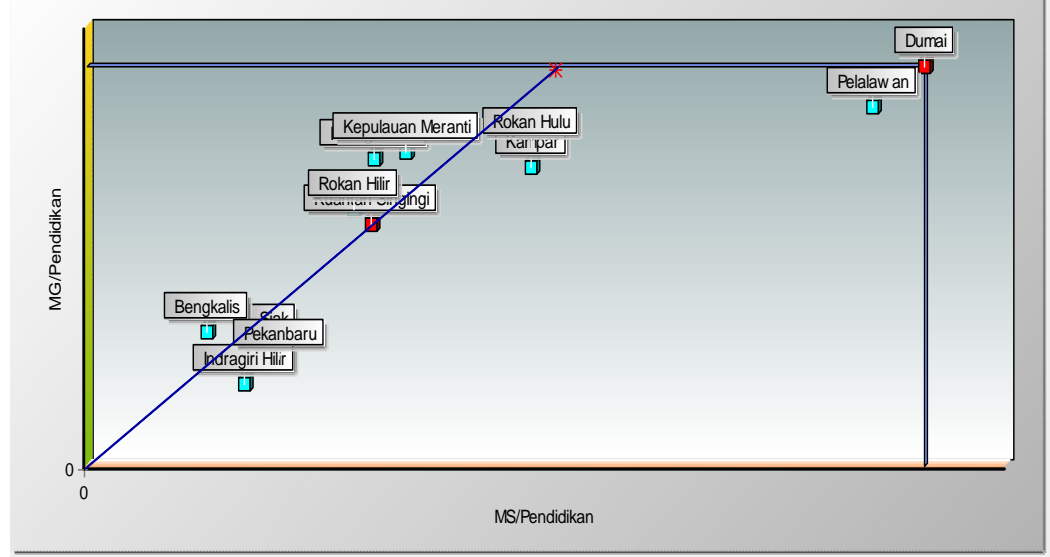

Source:DEA processed, 2013

Figure 7. Frontier Graph Efficiency district of the Riau Province 2011

Based on the picture above, the district/city needs to make improvements to achieve the level of efficiency of education spending both in terms of input (educational affairs spending) and the output (studentteacher ratio or students to school ratio). Potential improvement that needs to be done by Bengkalis in 2011 from the input side is to reduce education spending by 66.44 percent. Besides the reduction in education spending, to achieve the necessary level of efficiency accompanied by an increase in the ratio of students to school (school capacity) of 136,28 percent.

The next, in 2012 the overall potential improvement that needs to be done in the form of improved inputs namely reduction education budget by 98,83 percent and the ratio of students per teacher was 1,17 percent. The need to reduce the education budget indicates that the use of the education budget in most districts/cities in Riau province does not produce the maximum output. In other words, the output in 2012 should be generated through the budget in that period. The use of education budget in 2012 in most of the district/city is said to be inefficient. In addition, the existing budgets need capacity building of teachers in dealing with students. In detail, the overall improvement of the district/city to achieve the level of efficiency is as follows.

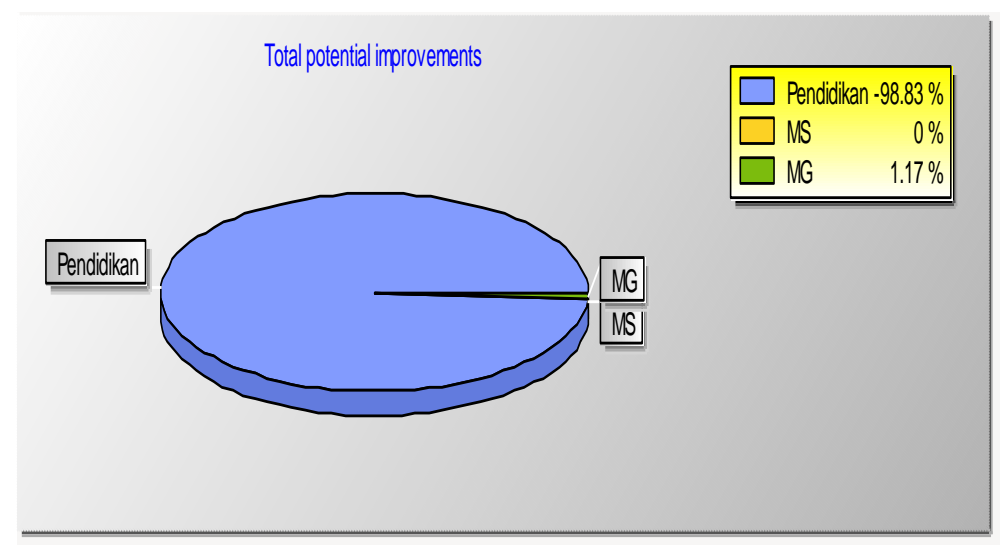

Source:DEA processed, 2013

Figure 8. Potential Overall Improvement 2012

In 2012, from all districts/cities in Riau Province, the Meranti Islands and Dumai is an area that is efficient in conducting education spending, with the achievement of an efficiency of 100 percent. While the others district/city are not categorized in this areas so the other district are not efficient. Inefficiencies in other districts in education spending due to the availability of output in 2012, should the value of the budget year in question needs to be reduced. The level of efficiency of each city in Riau province as follows. 


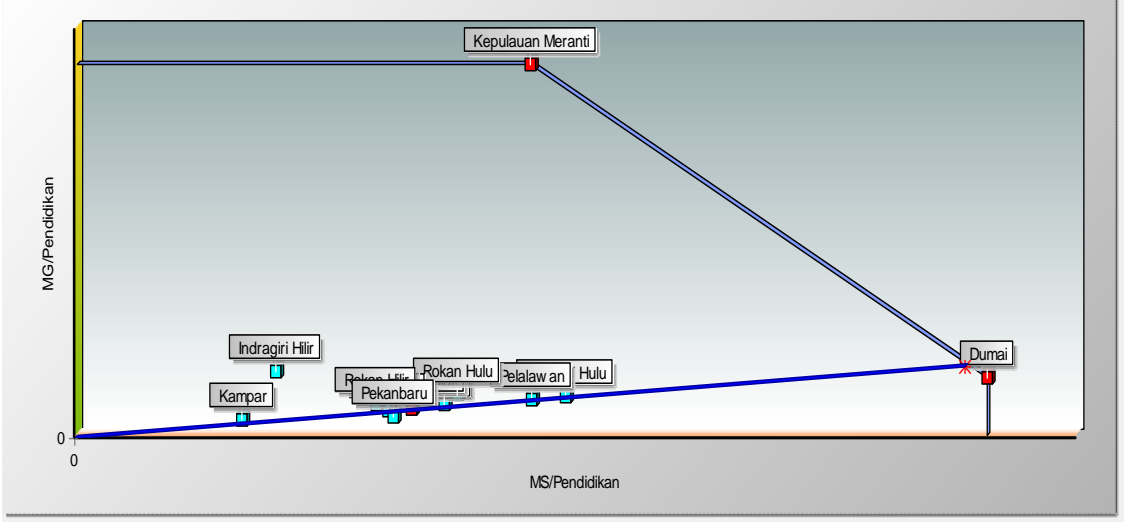

Source:DEA processed, 2013

Figure 9. The Efficiency Probability Rate

In 2012, all districts/cities in Riau Province are not efficient in conducting educational expenditure, need to do a potential improvement by reducing inputs (education expenditure) to achieve the level of efficiency. Although, there is one area,Pekanbaru in 2012 need to make improvements not only in terms of input, but also in terms of output. Bengkalis need to reduce the education budget by 65,11 percent to reach a level of efficiency. Similarly Indragiri downstream need to reduce education spending by 70,66 percent to reach a level of efficiency.

Then Indragiri Hulu also needed to reduce the budget by 45,15 percent to have this level of efficiency. Furthermore, Kampar district needs to cut its education budget too by 81,18 percent. Similarly, Kuantan Singingi inputs that need improvement by reducing the budget by 62,41 percent. Still the same as some other areas, each of Pelalawan, Rokan Hilir, and Siak must reduce education spending by 49,10 percent, 65,34 percent, 55,82 percent and 58,71 percent to reach a level of efficiency. Slightly different from the other district/city, the Pekanbaru in 2012 need to make improvements on the two sides, input and output. From the input side, there should be a reduction in the education budget by 65,28 percent. Then, in terms of output needed to handle an increase in the pupil teacher capacity by 7,33 percent.

\section{Usage Effectiveness Output to Outcome}

The calculation of the effectiveness of education in the district / city of Riau province is a measure of the utilization of the output to produce outcomes. In this measurement, the output used is the number of studentteacher ratio and the ratio of the number of pupils on the school number. While the outcome used is the literacy rate and the drop-out rate. Just as the calculation of the efficiency, effectiveness calculation method also uses Data Envelopment Analysis (DEA), which in perhitunganya district / city in question became effective when the score is equal to $100 \%$ effectiveness. If less than that, then the district / city is not effective.

To achieve the level of effectiveness in 2010, the overall improvement is needed is to reduce the dropout rate at the junior level by 3 percent and the dropout rate at the high school level amounting to 99,96 percent. Graphic illustration of the potential overall improvement is as follows.

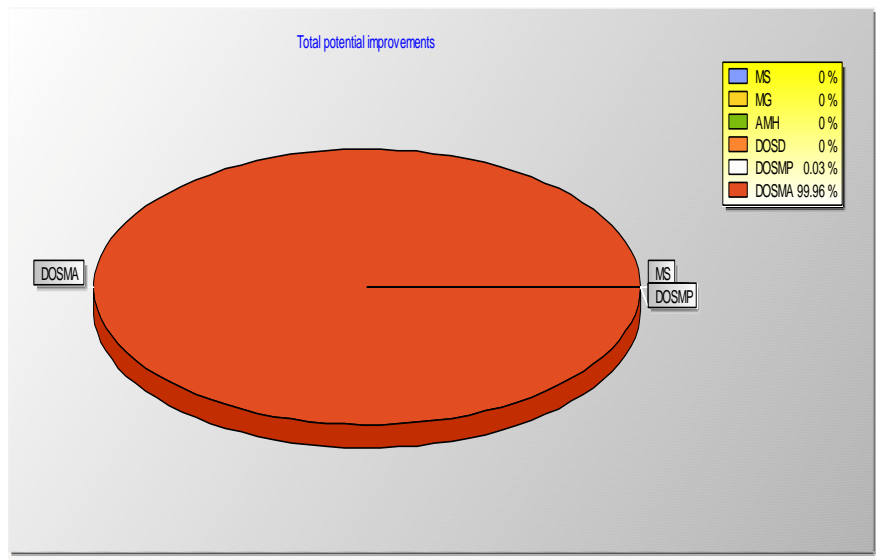

Source:DEA processed, 2013

Figure 10. Potential Overall Improvement Output/Outcome 2010 
To achieve the level of effectiveness in 2011, then the necessary repairs is to reduce the dropout rate at the elementary, middle, and high school respectively by 1,44 percent, 79,36 percent and 19,2 percent. This indicates that the improvements to be made on the dropout rate at the junior high school level is quite high. Overview of the potential overall improvement of the effectiveness of the district / city of Riau province are as follows.

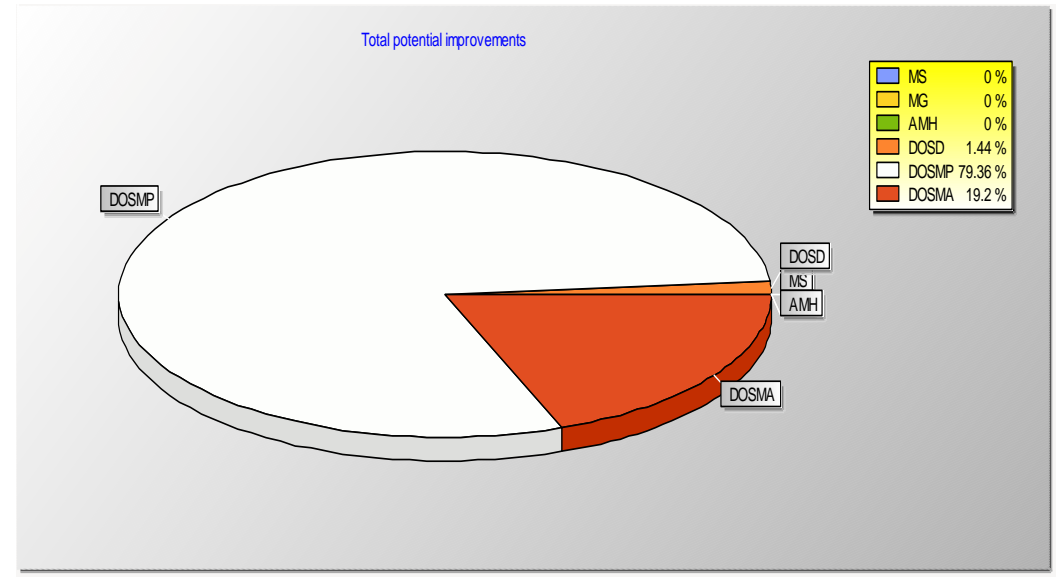

Source:DEA processed, 2013

Figure 11. Potential Overall Improvement Output/Outcome 2011

To achieve the level of effectiveness in 2012, the necessary repairs is to reduce dropout rates at the elementary, middle, and high school respectively by 0,04 percent, 0,02 percent and 99.93 percent. This indicates that the improvements to be made on the dropout rate at high school education level is quite high. Overview of the potential overall improvement of the effectiveness of the district/city of Riau province are as follows.

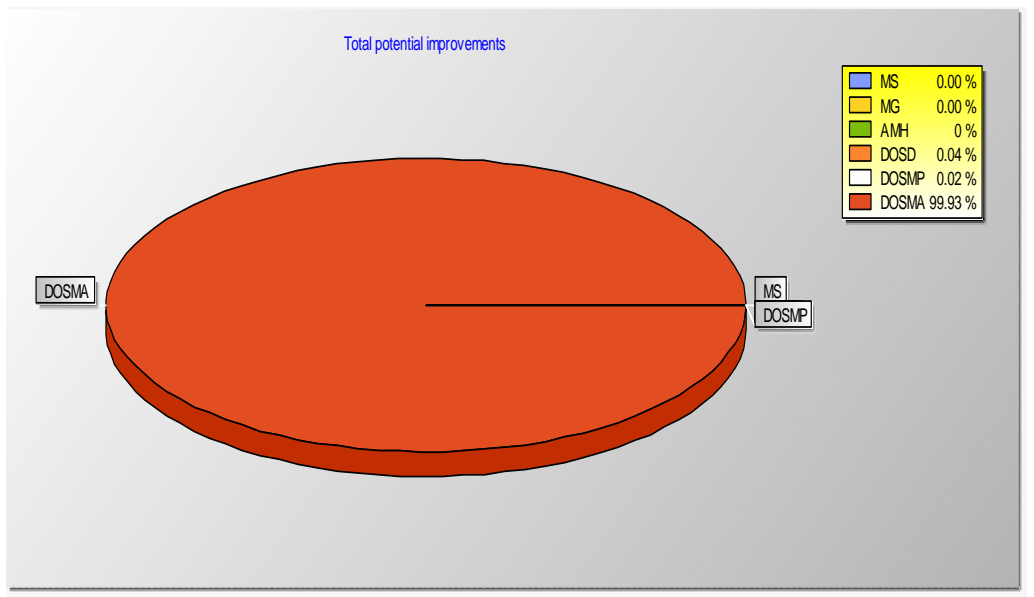

Source:DEA processed, 2013

Figure 12. Potential Overall Improvement Output/Outcome 2012

\section{Conclusion}

1. Secondary basic education financing in Riau Province financing educational performance imbalance occurs between the city therefore necessary policies aimed at reducing disparities in education funding through the efficiency and effectiveness of programs and activities. The policy was carried through the optimization of financing the achievement of outcomes-based education

2. Allocation of education funding in some districts/cities are still not in accordance with the needs of the area therefore necessary policies aimed at improving the educational planning in accordance with local needs and priorities. 


\section{References}

[1]. Abhijeet, Chandra. 2010. Does Government Expenditure on Education Promote Economic Growth? An Econometric Analysis. Forthcoming in: Journal of Practicing Managers

[2]. Azariadis, Costas and Allan Drazen, 2009, Thresh Old Externalities in Economic Development, Quarterly Journal of Economic, May 1990

[3]. Ahmed, Q. M, Javed, S and Loth, A. 2001, The Determinant of Public Expenditure A Simultaneous Approach- An Experience from Selected Developing counties, The Indian Economic Journal, Volume 48

[4]. Blaug, Mark, 2010, Approaches to the Analysis of Government Expenditure Growth, Public Finance Quarterly7:3-23

[5]. Barro, Robert J, N., 1990, Human Capital and Economic Growth, American Economic Review, Vol.98 No.5

[6]. Becker, Gary S. 1975, Human Capital: A Theoritical Approach and Empirical Analysis with Special Reference to Education, New York: Columbia University Press

[7]. Cunningham, I. (2002), Developing human and social capital in organisations, Industrial and Commercial Training, Vol. 34, No.4. 89-94.

[8]. Elchanan, C, 2007, Return to Education : A Further International Update and Implications,Journal of Human Resources,20,538597

[9]. Gupta, K. 2009, Public Expenditure on Education and Literacy Levels: A Comparative Study. State University at Stony Brook.

[10]. Hari, KS, 2008, Economic Growth \& Human Development Empirical Eviden from India State, Centre for Development Studies

[11]. Jones, 2010, Can Education Expenditure Reduce Income Equality, Economic of Education Review 21.

[12]. Lin, T.C. 2003, Education, Technical Progress and Economic Growth: The Case of Taiwan, Economic of Education Review 22:213-220

[13]. Lindauer, David L. and Velenchik Ann D, 1999, Government Spending in Developing Countries: Trends, Causes, Consequences, The World Bank Research Observer, Vol.7, No.1 :66-70

[14]. Mackanzie, G A. 2011 Education. Dalam Chu, K Y and Hemming R. Public Expenditure Handbook : A guide to Policy Issues in Developing Countries. IMF Washington D C.

[15]. Pryor, F. L., 1968, Public Expenditure in Communist and Capitalist Nations, London:George Allen and Unwin

[16]. Schultz, Theodore, W (1961), Investment in Human Capital, The American Economics Review, No. 51, March 1961

[17]. _ _ 2010. Unicef/Human Development Report 2010,http;//www.undp.org/ dr2002/indicator

[18]. - -----------,2012 Millenium Development Goals/MDGs di Kawasan Asia Pasifik.

[19]. ---------2003. Undang-Undang Nomor Nomor 20 Tahun 2003 tentang Sistem Pendidikan Nasional, www.depdiknas.go.id/ph/pdf 